\title{
THE POPULATION OF THE BRONZE AGE OF THE LOWER VOLGA REGION IN THE WORKS OF RUSSIAN ANTHROPOLOGISTS ${ }^{1}$
}

\author{
Evgeny V. Pererva \\ Volgograd Institute of Management, Branch of the Russian Presidential Academy of National Economy \\ and Public Administration, Volgograd, Russian Federation
}

\author{
Alexandr N. Djachenko \\ Volgograd State University, Volgograd, Russian Federation
}

\begin{abstract}
Introduction. This work is a review of scientific publications on studying paleoanthropological materials of the Bronze Age originating from burial mounds of the Lower Volga region. Materials and Analysis. The paper begins with the analysis of articles and monographic studies of domestic authors, whose works were written in the period from the 30s to the late $80 \mathrm{~s}$ of the $20^{\text {th }}$ century. The so-called Soviet period in Russian anthropology is characterized by the dominance of the individual-typological approach in describing skeletal series of representatives of the Bronze Age cultures. The osteological collections from burial complexes of the Bronze Age of the Lower Volga region accumulated at this stage of the study were distinguished by a small number and low representativeness. The main conclusions were based on studying craniological samples. A great contribution to developing ideas on the racial and ethnic history of the Lower Volga region during this period was made by researchers G.F. Debets, V.V. Gizburg, V.I. Vuich, B.V. Firshtein, A.V. Shevchenko. Thesecond part of the article is devoted to analyzing the results of anthropological research in the region in the works of modern Russian scientists. A distinctive feature of these works is that they are based on studying large-scale craniological series of broad temporal and territorial coverage. The studies of such scientists as A.A. Khokhlov, E.F. Batieva, A.A. Kazarnitsky, M.A. Balabanova use the complex approach in which classical methods of physical anthropology (craniology, osteology) are combined with the methods of statistical analysis and using data from Archaeology, Paleodemography, and Paleoecology. Results. The work shows the importance of using anthropological data as an independent source in paleohistorical constructions, as well as in the process of the archaeological study of various cultures of the Bronze Age that existed in the Lower Volga region.
\end{abstract}

Key words: Bronze Age, Lower Volga region, paleoanthropology, osteology, craniology, history.

Citation. Pererva E.V., Djachenko A.N. The Population of the Bronze Age of the Lower Volga Region in the a Works of Russian Anthropologists. Vestnik Volgogradskogo gosudarstvennogo universiteta. Seriya 4. Istoriya. ¿े Regionovedenie. Mezhdunarodnye otnosheniya [Science Journal of Volgograd State University. History. Area Studies. International Relations], 2019, vol. 24, no. 3, pp. 205-223. (in Russian). DOI: https://doi.org/10.15688/jvolsu4.2019.3.18

\section{НАСЕЛЕНИЕ БРОНЗОВОГО ВЕКА НИЖНЕГО ПОВОЛЖЬЯ В ТРУДАХ ОТЕЧЕСТВЕННЫХ АНТРОПОЛОГОВ ${ }^{1}$}

\section{Евгений Владимирович Перерва}

Волгоградский институт управления - филиал Российской академии народного хозяйства и государственной службы при Президенте РФ, г. Волгоград, Российская Федерация 


\title{
Александр Николаевич Дьяченко
}

\author{
Волгоградский государственный университет, г. Волгоград, Российская Федерация
}

\begin{abstract}
Аннотация. Данная работа является обзором научных публикаций, посвященных исследованию палеоантропологических материалов бронзового века, происходящих из курганных могильников Нижнего Поволжья. Очерк начинается с анализа статей и монографических исследований отечественных авторов, работы которых были написаны в период с 30-х по конец 80-х гг. ХХ столетия. Так называемый советский период в российской антропологии характеризуется доминированием индивидуально-типологического подхода при описании скелетных серий носителей культур бронзового века. Остеологические коллекции из погребальных комплексов эпохи бронзы Нижнего Поволжья, накопленные на этом этапе исследований, отличались немногочисленностью и малой репрезентативностью. Основные выводы базировались на изучении краниологических выборок. Большой вклад в развитие представлений о расовой и этнической истории Нижнего Поволжья в этот период был внесен такими исследователями, как Г.Ф. Дебец, В.В. Гизбург, В.И. Вуич, Б.В. Фирштейн, А.В. Шевченко. Вторая часть статьи посвящена анализу результатов антропологических исследований в регионе в трудах современных российских ученых. Отличительной особенностью этих трудов является то, что они базируются на изучении масштабных краниологических серий широкого временного и территориального охвата. В исследованиях таких ученых, как А.А. Хохлов, Е.Ф. Батиева, А.А. Казарницкий, М.А. Балабанова, используется комплексный подход, в котором классические методы физической антропологии (краниология, остеология) сочетаются с методами статистического анализа и использованием данных археологии, палеодемографии, палеоэкологии. Представленная работа показывает важность использования антропологических данных как самостоятельного источника при палеоисторических построениях, а также в процессе археологического изучения различных культур бронзового века, существовавших на территории Нижнего Поволжья. Вклад авторов: Е.В. Перервой написано введение, аналитическая и заключительная части работы, А.Н. Дьяченко - вводная часть исследования и заключение.
\end{abstract}

Ключевые слова: бронзовый век, Нижнее Поволжье, палеоантропология, остеология, краниология, история.

Цитирование. Перерва Е. В., Дьяченко А. Н. Население бронзового века Нижнего Поволжья в трудах отечественных антропологов // Вестник Волгоградского государственного университета. Серия 4, История. Регионоведение. Международные отношения. - 2019. - Т. 24, № 3. - С. 205-223. - DOI: https://doi.org/10.15688/ jvolsu4.2019.3.18

Введение. Первые попытки научного подхода к изучению истории Нижнего Поволжья были предприняты в путевых журналах Петра I, которые впоследствии явились основой для написания первого полноценного исторического труда «Гистория Свейской войны» [19]. Работа над его созданием велась практически на протяжении всего периода правления Петра І. Считается, что некоторые сюжеты писались непосредственно при личном участии Петра I [35, c. 113]. Большое значение для изучения истории региона имеют заметки и научные описания, составленные иностранными путешественниками и учеными XVII-XVIII вв., например Корнелием де Бруином, Джоном Беллом, Джоном Перри, Филиппом Иоганном фон Страленбергом [10; 24; 49; 50]. Дальнейшее изучение истории Нижнего Поволжья связано с работами ученыхэнциклопедистов И.И. Лепехина, С.Н. Гмелина, Н.Я. Озерецковского, Фалька и П.С. Палласа $[35 ; 36]$. Эти исследователи в рамках на- учных экспедиций, организованных Российской академией наук, собирали сведения по географии, этнографии, земледелию, скотоводству, состоянию промышленности.

Однако подлинное осмысление исторического наследия племен и народов, проживавших на территории Нижнего Поволжья в древности и средневековье, было осуществлено значительно позднее - в ХХ веке. Именно в этот период начинается активное изучение археологических памятников в Нижневолжском регионе. Масштабные полевые работы в это время ведутся в Саратовской, Волгоградской (Сталинградской), Астраханской областях, а также в Республике Калмыкия. Результаты полевых и камеральных исследований нашли свое отражение в публикациях отечественных археологов, среди которых следует выделить П.С. Рыкова, П.Д. Рау, Б.Н. Гракова, М.И. Артамонова, И.В. Синицына, К.Ф. Смирнова, В.П. Шилова, Г.А. Федорова-Давыдова. 
Параллельно с изучением археологических памятников шел процесс накопления материалов, позволяющих исследователям судить о физическом облике древних людей. Этому обстоятельству благоприятствовало открытие в Нижнем Поволжье целого ряда погребальных памятников бронзового и раннего железного веков, которые в подавляющем большинстве случаев представлены подкурганными захоронениями. Антропологические данные, накопленные более чем за столетнюю историю изучения объектов археологии Нижнего Поволжья, получили серьезную аналитическую проработку в трудах отечественных антропологов. Уже классическими стали работы Г.Ф. Дебеца [22], Л.Г. Вуич [16], В.В. Гинзбурга [18], Н.М. Глазковой и В.П. Чтецова [20], Б.В. Фирштейн [67], А.В. Шевченко [64]. На основании краниологических исследований представителей эпохи бронзы были выявлены морфологические особенности, составляющие антропологический облик той или иной археологической культуры. Проделанная работа позволила ученым наметить пути решения такой проблемы, как формирование расово-генетических комплексов у носителей археологических культур Нижнего Поволжья, оценить степень влияния миграций на генезис населения периодов ранней, средней и поздней бронзы.

Анализ. Историю развития палеоантропологии Нижнего Поволжья условно можно разделить на два больших этапа - советский и современный.

Первый этап начинается во второй четверти XX в. с работ Г.Ф. Дебеца и заканчивается 90-ми гг. этого же столетия. Его можно охарактеризовать как время накопления палеоантропологического материала и доминирования в исследованиях методов классической физической антропологии (краниологии).

Второй этап охватывает период с середины 90-х гг. прошлого века по настоящее время. На этом этапе продолжаются исследования в области классической антропологии, но большая часть научных разработок характеризуется междисциплинарным подходом; активно используются методы статистики, генетики, палеодемографии, палеопатологии и одонтологии.

Бронзовый век Нижнего Поволжья традиционного делят на три этапа: ранний, сред- ний и поздний [32; 33; 53]. В каждом из этапов рассматривается ряд культур, часть из них имеют общие генетические корни. Так, в рамках эпохи ранней бронзы на территории Нижнего Поволжья выделяют погребальные памятники культур древнеямного круга: репинской и константиновской. Средний бронзовый век представлен полтавкинской, волго-донской, среднедонской, волго-маныческой (маныческой) культурами, а также блоком посткатакомбных культур (культура многоваликовой керамики, криволукская и бабинская культуры). В рамках позднебронзового века рассматриваются подкурганные захоронения и стоянки покровской и срубной культур, а также памятники пострубного времени (культуры валиковой керамики) [34; 41].

Несмотря на культурное и морфологическое разнообразие, фиксируемое по археологическим и антропологическим находкам бронзового века, население его раннего периода и большей части среднего занималось хозяйством, ориентированным на скотоводство. Этот характер деятельности позволил носителям культур ранней и средней бронзы распространиться практически по всей степной зоне Восточной Европы [52; 53; 66].

В начале позднебронзового века в степях Волго-Уралья, как отмечают В.С. Бочкарев, П.Ф. Кузнецов, О.Д. Мочалов, имел место настоящий культурно-технологический взрыв, который отчасти был спровоцирован экологическими изменениями, связанными с гумидизаций климата [13; 39]. Новации оказали влияние не только на социально-экономическое развитие племен поздней бронзы, но также привели к изменениям их религиозно-погребальных традиций. Развивается комплексное хозяйство, что приводит, в свою очередь, к оседлости населения и появлению многочисленных долговременных поселений.

Впервые антропологические материалы эпохи бронзы Нижнего Поволжья были описаны в работе Г.Ф. Дебеца [21]. Черепам ямной культуры автор дал следующее описание: низкий и широкий лицевой отдел, наклонный лоб, мощные надбровные дуги. Такой комплекс признаков он отнес к так называемому протоевропейскому типу [21, с. 66].

Позднее антропологические материалы с территории Нижнего Поволжья Г.Ф. Дебе- 
цем были сгруппированы по культурному признаку: древнеямная культура, катакомбная культура и срубная культура. Общей чертой краниологических материалов всех трех культур бронзового века, по мнению исследователя, является то, что все они относятся к протоевропейский антропологическому типу. Автор указал на схожесть черепов ямной и срубной культур, при этом последние оказались более грацильными. Наличие у представителей катакомбной культуры брахикранного элемента позволило ученому сделать предположение о мигрантном происхождении ее носителей [22, с. 102-106, 328].

Существенное значение для понимания процессов культурогенеза в эпоху бронзы на территории Нижнего Поволжья имеет работа В.В. Гинзбурга, в которой автор представил результаты краниологического исследования материалов Калиновского курганного могильника, располагавшегося в Волгоградском Заволжье. Краниологический анализ костных останков показал, что черепа указанных археологических периодов относятся к выраженному европеоидному типу. Черепа древнеямной и срубной культур Калиновского могильника оказались очень близки по строению между собой и морфологически сходны с синхронными сериями с территории Нижнего Подонья [18, с. 524-525].

Выводы, сделанные В.В. Гинзбургом относительно материалов ранней бронзы, были подвергнуты критике со стороны М.А. Балабановой и А.А. Хохлова, которые, ссылаясь на работы современных археологов, установили, что из 8 черепов эпохи ранней бронзы, обследованных В.В. Гинзбургом, только один относится к позднеямному времени. Остальные материалы датируются эпохой средней бронзы $[2$, с. $77 ; 58]$.

Большое значение для изучения антропологического состава населения эпохи бронзы имела работа Н.М. Глазковой и В.П. Чтецова, в которой были проанализированы немногочисленные серии древнеямной (2 черепа), полтавкинской (4 черепа) и срубной (9 черепов) культур. Оценив доступные материалы эпохи ранней бронзы, исследователи пришли к выводу, что они схожи с черепами, которые были изучены Г.Ф. Дебецем. Их также отнесли к протоевропейскому типу. Чере- па полтавкинской культуры оказались ближе к брахикефалам катакомбных погребений, а черепа срубной культуры, как и у Г.Ф. Дебеца, в большей степени сходны с древнеямными, чем с черепами эпохи средней бронзы [20, с. 292].

Еще одной значительной работой советского этапа развития палеоантропологии Нижнего Поволжья является исследование Б.В. Фирштейн, проведенное на материалах могильников Саратовской и Волгоградской областей, а также Республики Калмыкия. В ее работе приводятся данные по 74 черепам: древнеямной (12), катакомбной (21) и срубной (41) культур [67, с. 100-101]. Изучение данной серии, сопоставление полученных результатов с предыдущими исследованиями материалов Нижнего Поволжья и сопредельных территорий позволили сделать вывод о том, что краниумы древнеямной культуры Волгоградской области находят морфологическое сходство с черепами этого же времени с территории Украины. Антропология населения срубного времени Волгоградской и Саратовской областей, по ее мнению, имеет два европеоидных варианта - долихокранный и мезобрахикранный, которые на территории Нижнего Поволжья складываются, скорее всего, под вливанием населения как западных (территория Украины), так и восточных (Западный Казахстан) областей. Морфологические особенности населения катакомбной культуры наибольшие аналогии находят в материалах левобережья Волги (Бережновские могильники) [67, с. 140].

Большой вклад в изучение антропологических особенностей населения бронзового века евразийских степей внес А.В. Шевченко. Первоначально ученым были опубликованы материалы анализа 27 черепных коробок, относящихся к древнеямной, катакомбной и срубной культурам. Костные останки происходили из курганных могильников юга Волгоградской и севера Астраханской областей [63]. В результате исследователь сделал вывод о том, что краниологические типы древнеямной, катакомбной и срубной культур Нижнего Поволжья являются локальными вариантами протоевропейского антропологического типа [63, с. 132-133].

Проанализировав характер этнических и эволюционных процессов в эпоху бронзы, оценив средние величины антропологических при- 
знаков, А.В. Шевченко отметил значительную степень сходства физического типа представителей древнеямной и катакомбной культур. В связи с этим он высказал предположение о возможном участии носителей древнеямной культуры в этногенезе населения катакомбной культуры.

В отличие от позиции Г.Ф. Дебеца [21; 22], а также Н.М. Глазковой и В.П. Чтецова [20], указывающих на близость антропологических типов древнеямной и срубной культур, А.В. Шевченко подобного рода связей не обнаружил. По его мнению, антропологический тип, распространенный у срубников Нижнего Поволжья, имеет аналогии с синхронным населением Среднего Поволжья, степной Украины, Прутско-Днестровского междуречья [63, с. 123].

Фундаментальным трудом, посвященным изучению антропологии населения южнорусских степей в эпоху бронзы, является работа А.В. Шевченко «Антропология населения южнорусских степей в эпоху бронзы», вышедшая в 1986 году. В данном исследовании, наряду с уже опубликованными материалами, ученым была проанализирована представительная серия черепов более чем 300 взрослых индивидов обоего пола. Костные материалы были сгруппированы в соответствии с рубриками археологических классификаций и датировокпо культурам и по регионам.

В результате анализа краниологических серий ямного времени А.В. Шевченко пришел к выводу, что для населения этого периода не существует единого антропологического типа [64, с. 154]. Ямники Нижнего Поволжья характеризуются значительным полиморфизмом. Их формирование на территории Калмыкии происходило за счет слияния трех компонентов, которые исследователь обозначил как $\mathrm{A}, \mathrm{B}$ и С. Краниологический тип «А» связан с неолитическим населением Приазовья - Надпорожья - Подонья. Тип «В» с морфологической точки зрения происходит из восточных районов ареала ямной культуры. Тип «С» имеет метисное происхождение, он формировался с участием населения, связанного с памятниками среднестоговского типа [64, с. 150]. Еще одной особенностью населения эпохи ранней бронзы Нижнего Поволжья, на которую обратил внимание А.В. Шевченко, является общая тенденция к увеличению массивности черепа и брахикефализация.

Исследование материалов катакомбного времени дало возможность автору сделать вывод о преобладании в данной серии долихокранных, гиперморфных типов. Эта специфика отмечена на сериях как деформированных, так и недеформированных черепов. Аналогии недеформированным черепам катакомбного времени с территории Калмыкии А.В. Шевченко находит в шнурокерамических сериях Средней Европы [64, с. 178].

Большое внимание автор уделял изучению серии деформированных черепов катакомбного времени. Исследователь предпринял попытку разобраться в проблеме происхождения обычая искусственной деформации черепа у населения эпохи средней бронзы Нижнего Поволжья. Отвечая на этот сложный вопрос, ученый приходит к заключению, что появление этого обычая связано с проникновением в предкавказские степи с территории Переднего и Среднего Востока (Восточной Анатолии) его носителей [64, c. 185].

В результате изучения краниологических серий срубного времени с территории Нижнего Поволжья А.В. Шевченко удалось выявить среди них модификации долихокранного морфологического типа и протоевропейский антропологический тип, аналоги которому присутствуют в краниологических материалах предшествующих культур: ямной, новосвободнинской, северокавказской, катакомбной и полтавкинской [64, с. 194]. Выявленная А.В. Шевченко сильная матуризация физического типа срубников Поволжья объясняется смешением срубного населения с ямно-полтавкинскими и абашевскими племенами. К этому же выводу автор приходит и в более поздней своей работе, посвященной сравнительно-антропологическому анализу срубных групп Поволжья. В результате привлечения всех известных на то время палеоантропологических серий А.В. Шевченко вновь делает заключение о том, что все население бронзового века Восточной Европы отличалось крайним краниологическим полиморфизмом и, соответственно, расовым многообразием [65, с. 101102]. Данная ситуация, по мнению автора, характерна и для срубного населения Повол- 
жья, происхождение которого он связывает с западным влиянием [65, с. 105].

Одним из важнейших достоинств работ А.В. Шевченко является то, что многие выводы сделаны им в результате аналитической работы с массовым серийным материалом эпохи бронзы. Его работа «Антропология населения южнорусских степей в эпоху бронзы» является наиболее продвинутым вариантом индивидуально-типологического описания древних популяций, на основании которого была предложена модель многокомпонентного антропологического состава населения эпохи бронзы Восточно-Европейской степи.

Для нового этапа развития отечественной физической антропологии начиная с середины 90-х гг. XX в. характерна тенденция к ликвидации значительной части белых пятен в палеоантропологии эпохи бронзы ВосточноЕвропейской степи. Массовое накопление материала, а именно краниологических и остеологических серий, позволило отечественным ученым рассматривать культурно-исторические общности бронзового века с позиций популяционного подхода на уровне регионов, могильников, курганов и даже отдельных погребений. В немалой степени этому поспособствовало развитие региональных центров по изучению палеоантропологических материалов, например, в Самаре, Ростове-на-Дону, Челябинске, Волгограде. Весомый вклад в изучение антропологии древнего населения эпохи палеометалла внесли такие исследователи, как С.И. Круц [38], Л.Т. Яблонский [68], А.А. Хохлов [54; 56; 59; 61], М.М. Герасимова [17], Е.П. Китов [31], А.А. Казарницкий [27], Е.Ф. Батиева [9], М.А. Балабанова [2] и многие другие.

Кратко остановимся на работах, в которых проанализированы антропологические материалы сопредельных с Нижним Поволжьем территорий.

В первую очередь следует обратить внимание на работы Е.Ф. Батиевой по изучению физических особенностей населения эпохи бронзы Нижнего Подонья, а также на труды А.А. Хохлова - основателя Самарской школы антропологов, посвятившего большую часть своих исследований поиску решения проблем происхождения древнего населения лесостепного Поволжья.
Анализ обширных краниологический серий позволил Е.Ф. Батиевой оценить характер изменчивости антропологических типов древнего населения Нижнего Подонья в эпоху бронзы. У группы раннего бронзового века исследователь обнаружила два локально-территориальных типа: правобережный (мезокранный) и левобережный (долихокранный). Длинноголовость населения ранней бронзы Е.Ф. Батиева объясняет влиянием элементов раннекатакомбной культуры. У групп эпохи средней бронзы автор отмечает широкое распространение долихомезокранного типа с хорошо профилированным лицом. На материалах посткатакомбного времени (культура многоваликовой керамики) Е.Ф. Батиева выявляет в женской выборке сохранение типичного мезабрахикранного комплекса, характерного для предшествующего времени [5, с. 131]. А вот мужская серия, по ее мнению, демонстрирует доминирование долихокранного типа с узким и высоким лицом [5, с. 131].

Изучив краниологические выборки срубно-абашевских погребений поздней бронзы междуречья Дона и Чира, она делает вывод об их принадлежности к средиземноморскому варианту большой европеоидной расы [5, c. 133]. В результате межгруппового анализа автор приходит к заключению, что исследованные черепа срубного времени по своим характеристикам близки к нижневолжским сериям [9, с. 237].

Большое внимание Е.Ф. Батиева уделяет изучению и других специфических антропологических проблем населения бронзового века Нижнего Подонья, например случаям трепанации черепа [6] и обычаям преднамеренной искусственной деформации [8]. Ею также были разработаны проблемы, связанные с палеодемографическими перекосами у населения бронзового века Подонья. Так, исследователь выявил тенденцию увеличения средней продолжительности жизни населения от ранней бронзы к позднебронзовому периоду, уменьшение смертности в ранних возрастах, особенно в женских выборках, а также увеличение доли индивидов старческого возраста. Кроме того, она предположила, что выявленные демографические особенности и дисгармонии у населения бронзового века могут быть связаны с глобальными экологи- 
ческими кризисами или трансформациями в хозяйственной деятельности [7, с. 244].

Неоценим вклад в изучение населения бронзового века А.А. Хохлова, который начиная с середины 90-х гг. XX в. особое внимание уделял проблемам палеоантропологии Самарского Заволжья, Оренбургской области, Южного Приуралья, Волго-Уральских степей, Западного Казахстана и Предкавказья.

Результатом многолетних исследований по систематическому накоплению и обработке палеоантропологического материала явилась работа А.А. Хохлова «Палеоантропология Волго-Уралья эпох неолита - бронзы» [58]. В этом фундаментальном труде автор проанализировал ход изменений морфологических особенностей у населения бронзового века, а также рассмотрел вопросы генезиса культур, определявших облик населения ранней, средней и поздней бронзы ВолгоУральского региона.

Так, по мнению исследователя, носители ямной культуры в рассматриваемой части ойкумены были типичными европеоидами. В основе формирования их облика лежали процессы хвалынско-среднестоговских контактов еще в энеолитический период в пограничном для этих культурных образований Доно-Волжском ареале (ближе к Дону) с подключением западных групп гиперморфного облика. Формировавшийся пласт населения (в том числе в лице носителей репинской культуры), сдвигаясь на восток - в районы Заволжья, включал в свой состав местные постхвалынские группы. Результатом этого процесса в антропологическом контексте явилось сложение полиморфного европеоидного населения при доминировании матуризованного, мезокранного, широколицего компонента, а в археологическом - волго-уральского варианта ямной культуры [58, с. 24; 61, с. 74, 75, 144].

С началом этапа средней бронзы в лесостепном и степном Поволжье распространяются носители полтавкинской культуры. Сложение их морфологического типа, по мнению А.А. Хохлова, происходило на местной ямной основе с привлечением южных степных скотоводческих групп [58, с. 25].

Дальнейшие изменения в антропологии населения эпохи средней бронзы автор связывает с появлением южноевропейского степ- ного краниологического комплекса, носителями которого являются представители криволукской культурной группы. Определенное влияние на облик населения Волго-Уралья, по мнению А.А. Хохлова, оказали популяции, практиковавшие преднамеренную искусственную деформацию головы. Автор считает, что данный обычай в степи Поволжья был привнесен представителями восточно-маныческой культуры [58, с. 25]. Кроме того, А.А. Хохлов обратил внимание на изменения в антропологических комплексах, которые происходили в период перехода от среднебронзового века к позднебронзовому периоду. Эти трансформации связаны с появлением культур потаповско-синташтинского круга, которым автор отдельно и совместно с Е.П. Китовым посвятил значительное число работ [58; и др.]. Основные позиции исследователей свелись к следующему.

Для этого населения фиксируется резкий краниологический полиморфизм на внутригрупповом уровне и выраженная политипия на межгрупповом, контрастно выделяющая население этой культуры на фоне других популяций эпохи бронзы.

В составе этого блока культур отмечаются различные варианты индивидов европеоидной, уралоидной рас, а в единичных случаях фиксируется проявление монголоидности. Доминируют европеоидные краниологические варианты гиперморфного облика.

Сложение физического типа этого населения происходило на основе взаимодействия носителей степных поволжско-казахстанских культур с представителями лесостепных групп, в том числе абашевской [62].

На основе синташтинцев складывается антропологическая специфика носителей петровской культуры Южного Урала, а при их взаимодействии с лолинскими группами Предкавказья, а также криволукскими потомками Нижнего Поволжья формируется облик покровского (раннесрубного) населения, а затем и срубного позднего этапа бронзового века [61].

В процессе изучения населения бронзового века Волго-Уральского региона А.А. Хохлова интересовали проблема наличия монголоидной примеси на черепах носителей срубной культуры [57], вопрос взаимосвязи ямной 
культуры Восточной Европы и афанасьевской культуры Южной Сибири [60], причина распространения преднамеренной искусственной деформации у населения эпохи средней бронзы, а также проблемы половозрастной структуры культур эпохи бронзы и многие другие аспекты расовой антропологии, связанные с этнокультурным взаимодействием степного и лесостепного населения Восточной Европы.

Существенное внимание А.А. Хохловым было уделено изучению палеоантропологических серий бронзового века с территории Нижнего Поволжья, прежде всего материалов ранней бронзы. В результате анализа морфологических особенностей представителей ямной культуры Калмыкии ученый делает вывод о наличии в степях Прикаспия особого очага расогенеза. Комплекс таких признаков, как брахикрания в сочетании с широким и относительно низким лицом, резко отличает ямников Калмыкии от других носителей ямных традиций. Появление этого комплекса А.А. Хохлов связывал с хвалынским населением, а также с проникновением в состав древнеямного субстрата какого-то еще неизвестного антропологического компонента [56, c. 144-145].

Значительный вклад в изучение морфологии древнего населения южнорусских степей внесла волгоградский антрополог М.А. Балабанова. Исследование антропологических серий эпохи энеолита и ранней бронзы с территории волгоградской области позволило ей прийти к выводу, что население этого периода было неоднородным. Большая часть черепов ямного времени характеризуется ею как широколицый европеоидный вариант, в котором выделяется два морфологических типа: мезоморфный и геперморфный. Антропологическая серия энеолита и ранней бронзы находит аналогии с синхронными ямными группами Самарского Заволжья, Оренбуржья и майкопской культурой, отличаясь при этом от южных серий Калмыкии и астраханского Правобережья [2, с. 81].

Тщательный анализ костных останков катакомбного времени позволил М.А. Балабановой поддержать точку зрения А.В. Шевченко о существовании двух компонентов, на основании которых мог формироваться антропологический облик катакомбного населе- ния: пришлый средиземноморский и местный протоевропеоидный [1, с. 50].

М.А. Балабановой проведены комплексные исследования остеологических серий эпохи бронзы из могильника Перекопка в излучине Дона, могильников Островной, Малые Дербеты I и II, Ергенинский I Республики Калмыкия [3]. Особое внимание исследователь уделяла проблеме распространения обычая преднамеренной искусственной деформации у населения эпохи бронзы, а также палеодемографическим особенностям населения бронзового века и стратегии выживания неполовозрелых групп в этот период истории [3; 4 ].

В настоящее время наиболее целенаправленные исследования палеоантропологических материалов бронзового века Нижнего Поволжья проведены А.А. Казарницким. Начиная с 2009 г. им была опубликована целая серия статей, посвященная изучению палеоантропологии населения Северо-Западного Прикаспия. Существенное внимание было уделено анализу краниологических материалов майкопской, ямной и посткатакомбных культур [25; 26; 28-30].

Научным обобщением этих исследований явился монографический труд «Население Азово-Каспийских степей в эпоху бронзы» [27]. Материалом для данной работы послужили краниологические, остеологические и краниоскопические серии с территории Республики Калмыкия, Ростовской, Волгоградской и Астраханской областей. Достоверность представленных результатов в этом труде подтверждается широким спектром применяемых антропологических приемов и использованием методов статистического анализа при исследовании внутригрупповой и межгрупповой изменчивости [27].

По мнению А.А. Казарницкого, в период от мезолита до ранней бронзы население Восточной Европы состояло преимущественно из двух популяционных генеологических линий. Одна из этих линий связана с памятниками неолитического времени и носителями хвалынской и среднестоговской энеолитических культур, а вторая - с неолитическим населением Днепровского Надпорожья. Именно вторую линию развития А.А. Казарницкий определяет как исходную для происхождения па- 
леопопуляций эпохи ранней бронзы СевероЗападного Прикаспия [27, с. 146-147].

Население майкопской культуры, которое характеризуется комплексом южных европеоидов и имеет переднеазиатское происхождение, оказало существенное влияние на формирование облика степного населения культур эпохи ранней бронзы. Краниологические особенности раннекатакомбной культуры Калмыкии носят на себе следы прямой генетической преемственности с населением ямной культуры этого же региона. Черепные серии катакомбной культуры Калмыкии, Волгоградской и Ростовской областей, как указывает А.А. Казарницкий, вероятнее всего, испытывали серьезное влияние в связи с миграциями групп населения с Юга, что подтверждается удлинением мозговой коробки и распространением искусственной деформации [27, с. 181]. Тенденция к уменьшению ширины черепной коробки и ее лептоморфности отмечена автором и на материалах финала средней бронзы и периода поздней бронзы. Так, именно на черепах лолинской и срубной культур автором фиксируется специфический морфологический комплекс, характеризующийся долихокранией и узким клиногнатным лицом [27, с. 182].

Таким образом, данные краниологического анализа материалов Северо-Западного Прикаспия указывают на крайнюю неоднородность населения бронзового века в Нижнем Поволжье. В то же время тенденции морфологических изменений имеют один вектор, который автор определяет как постепенное вытеснение представителей местных культур энеолита - ранней бронзы новыми группами населения, имеющими южную, возможно Закавказскую, основу. Как отмечает А.А. Казарницкий, этот процесс был постепенным, начинался с раннекатакомбного времени и завершился в эпоху поздней бронзы [27, с. 184].

Большинство рассмотренных выше работ, посвященных изучению различных групп населения бронзового века, построены в основном на анализе краниологических серий, являющихся наиболее массовым палеоантропологическим материалом. В то же время в арсенале современной физической антропологии существуют и другие методики и программы, предоставляющие дополнительную информацию об образе жизни человеческих кол- лективов древних эпох, стратегии их выживания, физическом облике и социально-культурных особенностях.

Наряду с краниологическими материалами антропологам часто приходится иметь дело с костями посткраниального скелета, которые являются важнейшим источником информации, позволяющим оценивать морфологический облик древнего населения и особенности его телосложения.

Первые случаи анализа костей посткраниального скелета даны в работе Г.Ф. Дебеца, где приводятся сведения о предполагаемом росте мужчин в эпоху ранней бронзы, укладывающемся в размер от 166 до $177 \mathrm{~cm}$ [22, c. 102-106].

В работе Н.М. Глазковой и В.П. Чтецова имеются расчеты роста одного из мужчин древнеямного времени. Исследователи сделали заключение, что по таблицам Троттер и Глезер высота его тела могла составить 186,3 см, что укладывается в разряд высокорослости [20, с. 285].

Интерес представляет работа А.А. Хохлова и С.Б. Боруцкой, которые проанализировав серии эпохи бронзы из могильника Манджикины Республики Калмыкия, пришли к выводу, что скелеты из этого могильника отличаются длинными ногами, широкими плечами, массивностью большеберцовых костей и позвоночника, а также средними значениями различных индексов. Рост женщин составляет около $160 \mathrm{~cm}$, а мужчин - 173-185 см. Мышечный рельеф костей скелета у ямников и катакомбников развит умеренно, а у срубников достаточно сильно. Авторы отмечают резко развитый мышечный рельеф костей и пояса верхних конечностей, что является отражением особых физических нагрузок, выпадающих на плечевой пояс [55, с. 219].

Несколько позднее С.Б. Боруцкой были опубликованы остеологические материалы ямного времени Северного Прикаспия. Автор делает вывод о том, что для большинства мужчин характерны средние или пониженные значения интермембрального указателя, средняя или большая ширина плеч, довольно высокий рост и средняя или высокая массивность скелетов [11, с. 194; 12, с. 291].

Остеологическое изучение серий Северо-Западного Прикаспия бронзового века 
было проведено и А.А. Казарницким [27]. Выявленные им специфические особенности в телосложении представителей некоторых культур бронзового века исследователь связывает с воздействием весьма значительных климатических колебаний, произошедших на рубеже III-II тысячелетий до н. э. и проявившихся в виде сильнейшей аридизации. Данные природно-климатические изменения, по мнению А.А. Казарницкого, могли стимулировать смену образа жизни племен бронзового века, что, в свою очередь, сказалось на колебании параметров телосложения [27, с. 178].

Существенное значение для понимания специфики образа жизни древних популяций имеют данные палеопатологических исследований. Начало этому научному направлению в нашей стране было заложено работами Д.Г. Рохлина [51], В.Я. Дэрумса [23] и др.

В настоящее время палеопатология как независимое научное направление в рамках отечественной антропологии развивается благодаря активной работе таких исследователей, как А.П. Бужилова [14; 15], М.Б. Медникова [42], М.В. Козловская [37] и др.

В данном контексте следует отметить ряд работ С.Б. Боруцкой, в которых автор приводит индивидуальные и обобщенные сведения о палеопатологии населения эпохи ранней и средней бронзы из могильников Республики Калмыкия. На антропологических материалах этого региона исследователем были отмечены разнообразные заболевания позвоночника: остеохондроз, спондилез, краевые разрастания. Кроме того, С.Б. Боруцкая выявила случаи пороза и периостита длинных костей скелета. Важная заслуга исследователя - выявление высокой встречаемости зубного камня и отсутствия на зубах признаков эмалевой гипоплазии у населения эпохи ранней бронзы. По мнению С.Б. Боруцкой, на материалах бронзового века достаточно редки травмы насильственного или боевого характера. Особенности развития мышечного рельефа на длинных костях посткраниального скелета свидетельствует о том, что пастушеские племена с территории Калмыкии, в особенности в эпоху ранней бронзы, передвигались пешком во время пастьбы, при этом большое значение у них имела работа руками [12, с. $291-$ 292; 55, c. 219].
Большое внимание проблемам палеопатологии населения эпохи бронзы Нижнего Поволжья уделяется в работах Е.В. Перервы. Им были исследованы и опубликованы индивидуальные данные по палеопатологии костных материалов из могильников Волгоградской области: Авиловский I и II, Перегрузное I, Перекопка I, II, III, IV, V, Линево, Песковка I, Гусевка I и II, Недоступов, Ольховка I и II [40; 43-47]. Изучались не только взрослые серии, но и детские. Исследователю удалось установить, что природно-климатические условия территории Нижнего Поволжья на протяжении всех трех периодов бронзового века существенно влияли на детские популяции. Климатические и географические условия региона определили особенности экономического уклада, а также специфику ведения хозяйства. Е.В. Перерва сделал предположение, что социальный статус детей в бронзовом веке был сравнительно низкий, что отражалось в слабой вовлеченности их в производственный процесс. На это указывает незначительное количество детских захоронений, отсутствие детского травматизма и признаков физической перегрузки на ранних этапах жизни. Процесс социализации в эпоху ранней и средней бронзы наступал с периодом полового созревания. Для детей бронзового века, скорее всего, было характерно длительное грудное вскармливание. Переход к обычной пище практически всегда сопровождался развитием стресса для детского организма и происходил не ранее 2,5-3 лет. Большое количество детей в захоронениях эпохи поздней бронзы объясняется изменением хозяйственного уклада и традиций. Кроме того, высокая детская смертность в эпоху поздней бронзы могла быть спровоцирована регулярными сезонными голодоморами [47, с. 51-56].

Интересные данные были получены в совместном исследовании Е.В. Перервы и А.Н. Дьяченко, посвященном поиску причин появления у степного населения эпохи средней бронзы такого патологического состояния, как экзостоз ушного канала. Авторами было установлено, что возможными причинами развития патологии могли быть стрессы, возникающие из-за воздействия природно-климатических факторов, специфики образа жизни, а также систематических воспалительных за- 
болеваний уха. Появление индивидов с ушным экзостозом в эпоху средней бронзы в Нижнем Поволжье, вероятнее всего, связано с переселением некоторых групп населения, возможно, с территории Закавказья, Северного Кавказа или Северного Причерноморья. Данное предположение соотносится с результатами палеоэкологических, археологических и краниологических исследований, подтверждающих возможные миграции какой-то части населения Предкавказья и Кавказа вследствие экологического кризиса в конце III - начале II тыс. до н. э. на север, в степные пространства Нижнего Поволжья [48].

Результаты. Анализ научных публикаций, посвященных изучению антропологических материалов бронзового века, происходящих с территории Нижнего Поволжья, позволяет сделать следующие выводы.

1. Советские антропологи, а также их современные российские коллеги на основании имеющихся антропологических источников отмечают значительное разнообразие морфологических типов населения ВосточноЕвропейских степей в эпоху бронзы. Это обусловлено в первую очередь тем, что развитие населения этой огромной территории происходило как на основе местных компонентов, так и под воздействием мигрантных групп с востока, юга и запада. Результаты археологических исследований подтверждают факт существенного влияния на характер эволюции степных культур бронзового века со стороны Кавказского и Волго-Уральского очагов культурогенеза [13, с. $118-119 ; 34$, с. $58 ; 39$, с. 291].

2. Не меньшее влияние на характер расового и морфологического развития носителей культур бронзового века степной полосы оказывали образ жизни и климатические колебания. Племена ранней и большей части средней бронзы, культивируя комплексное хозяйство, ориентированное на скотоводство, в кратчайшие исторические сроки расселились практически по всей степной зоне Восточной Европы [52; 53; 66]. В начале позднебронзового периода в ВолгоУральских степях произошел культурно-технологический взрыв, отчасти спровоцированный экологическими изменениями. Это привело к появлению целого ряда новаций в экономической сфере. Хозяйство культур эпо- хи поздней бронзы начинает носить земледельческо-скотоводческий характер. С распространением земледелия происходит оседание населения, что, в свою очередь, приводит к появлению множества долговременных поселений [13; 39].

3. Процесс накопления антропологических материалов бронзового века с территории Восточно-Европейской степи, начатый в начале XX в., продолжается и по настоящее время. Существенные достижения в решении проблем генезиса и эволюции носителей культур бронзового века, сделанные в советское время, находят продолжение в работах современных физических антропологов. Накопление остеологического материала в результате масштабных археологических исследований в Нижневолжском регионе позволил современным антропологам отойти от индивидуально-типологических характеристик и перейти к междисциплинарным исследованиям. Именно комплексный подход к анализу антропологических источников, базирующийся на популяционном подходе с применением различных измерительных методик и неметрических программ исследования, позволил современным ученым по-новому взглянуть на характер физической эволюции населения эпохи бронзы Нижнего Поволжья.

4. Широкое применение в исследованиях методов статистики, генетики и других естественно-научных направлений позволяет выявить ранее неизвестные факторы социального развития племен бронзового века, определить особенности их образа жизни, уровень технологического развития, специфику мировоззренческих представлений.

\section{ПРИМЕЧАНИЕ}

${ }^{1}$ Статья выполнена в рамках государственного задания Министерства образования и науки РФ, проект № 33.2830.2017/4.6 «Юг России в эпоху раннего железного века: диалог культур Восток Запад».

The article was carried out within the state task of the Ministry of Science and Higher Education of the Russian Federation, project no. 33.2830.2017/4.6 "South of Russia in the Era of the Early Iron Age: Dialogue of Cultures East - West". 


\section{СПИСОК СОКРАЩЕНИЙ}

$B A-$ Вестник антропологии.

МИА - Материалы и исследования по археологии СССР. вестник

$H A B$ - Нижневолжский археологический

ТГИМ - Труды Государственного исторического музея.

\section{СПИСОК ЛИТЕРАТУРЫ}

1. Балабанова, М. А. Катакомбная культура Волго-Донского междуречья по антропологическим данным / М. А. Балабанова // Археология Нижнего Поволжья: проблемы, поиски, открытия : материалы III Междунар. Нижневолж. археол. конф. (г. Астрахань, 18-21 окт. 2010 г.). - Астрахань : Издво Астрах. ун-та, 2010. - С. 48-50.

2. Балабанова, М. А. К антропологии населения энеолита - ранней бронзы (по материалам могильников Волгоградской области) / М. А. Балабанова // НАВ. - 2016. - Т. 15, № 1. - С. 72-94.

3. Балабанова, М. А. Детские погребения срубной культурно-исторической общности как объект междисциплинарного исследования / М. А. Балабанова // Stratum plus: Archaeology and Cultural Anthropology. - 2018. - № 2. - C. 245-258.

4. Балабанова, М. А. Антропологический аспект обычая искусственной деформации черепа у населения эпохи средней бронзы Нижнего Поволжья и сопредельных территорий / М. А. Балабанова // Самарский научный вестник. - 2018. T. 7, № 4 (25).-C. 219-227.-DOI: 10.24411/2309-43702018-14210.

5. Батиева, Е. Ф. Антропология срубно-абашевских погребений междуречья Дона и Чира / Е. Ф. Батиева // ВА. - 1999. - № 6. - С. 130-139.

6. Батиева, Е. Ф. Новые материалы по антропологии Нижнего Подонья / Е. Ф. Батиева // ВА. Альманах. -2001. - Вып. 7. - С. 116-124.

7. Батиева, Е. Ф. Палеодемография Подонья и Приазовья (эпоха бронзы) / Е. Ф. Батиева // ВА. 2007. - Вып. 15, ч. 2. - С. 236-245.

8. Батиева, Е. Ф. К вопросу об искусственной деформации черепа на Нижнем Дону в эпоху средней бронзы / Е. Ф. Батиева // Актуальные направления антропологии : сб., посвященный юбилею акад. РАНТ.И. Алексеевой. - М. : ИА РАН, 2008. - С. 26-33.

9. Батиева, Е. Ф. География антропологических типов древнего населения Нижнего Подонья (эпоха бронзы - средневековье) / Е. Ф. Батиева // Археологические записки : сб. науч. ст. - Ростов н/Д : Дон. археол. о-во, 2013. - Вып. 8. - С. 236-245.

10. Белевы путешествия чрез Россию в разныя асиятския земли, а именно: в Испаган, в Пекин, в
Дербент и Константинополь. В 3 ч. Ч. 3 / пер. с фр. М. Попова. - СПб. : При Императ. Акад. наук, 1776. $246 \mathrm{c}$.

11. Боруцкая, С. Б. Особенности физического типа населения эпохи бронзы Северного Прикаспия и Ростовской области / С. Б. Боруцкая // Позднекайнозойская геологическая история севера аридной зоны : материалы Междунар. симпозиума. - Ростов н/Д : Изд-во Ростов. гос. ун-та, 2006. C. 194-196.

12. Боруцкая, С. Б. Палеодемографические, остеологические и палеопатологические аспекты исследования популяций средней бронзы Республики Калмыкия / С. Б. Боруцкая // Роль естественнонаучных методов в археологических исследованиях. - Барнаул : Изд-во Алт. гос. ун-та, 2009. C. 289-293.

13. Бочкарев, В. С. Культурогенез и развитие металлопроизводства в эпоху поздней бронзы (по материалам южной половины Восточной Европы) / В. С. Бочкарев // Древние индоиранские культуры Волго-Уралья (ІІ тыс. до н. э.) : межвуз. сб. науч. тр. Самара : Изд-во СамГУ, 1995. - С. 114-123.

14. Бужилова, А. П. Древнее население : (Палеопатологические аспекты исследования) / А. П. Бужилова. - М. : ИА РАН, 1995. - 189 с.

15. Бужилова, А. П. Homosapiens : История болезни / А. П. Бужилова. - М. : Яз. слав. культур, 2005. $-320 \mathrm{c}$.

16. Вуич, Л. Г. Черепа из курганов эпохи бронзы и сарматского времени на левом берегу Нижнего Дона / Л. Г. Вуич // Материалы и исследования по археологии СССР. - 1958. - № 62. - С. 418-425.

17. Герасимова, М. М. К вопросу о происхождении ямной культуры / М. М. Герасимова // ВА. 2011. - № 19. - С. 104-111.

18. Гинзбург, В. В. Этнические связи древнего населения / В. В. Гинзбург // МИА. - 1959. - № 60. С. 324-594.

19. Гистория Свейской войны : (Поденная записка Петра Великого). Вып. 1 / сост. Т. С. Майкова ; под общ. ред. А. А. Преображенского. - М. : Круг, 2004. - 632 с.

20. Глазкова, Н. М. Палеоантропологические материалы нижневолжского отряда сталинградской экспедиции / Н. М. Глазкова, В. П. Чтецов // МИА. 1960. - № 78. - C. 285-292.

21. Дебец, Г. Ф. Материалы по палеоантропологии СССР. Нижнее Поволжье / Г. Ф. Дебец // Антропологический журнал. - 1936. - № 1. - С. 65-80.

22. Дебец, Г. Ф. Палеоантропология СССР / Г. Ф. Дебец. - М. : Изд-во Акад. наук СССР, 1948. -389 c.

23. Дэрумс, В. Я. Болезни и врачевание в старой Прибалтике / В. Я. Дэрумс. - Рига : Зинатне, 1970. - 199 c. 
24. Записки капитана Филиппа Иоганна Страленберга об истории и географии Российской империи Петра Великого. Северная и Восточная часть Европы. В 2 т. Т. 1 / под ред. М. П. Ирошникова. М. ; Л. : Ин-т истории СССР АН СССР, 1985. - 446 с.

25. Казарницкий, А. А. Краниология населения лолинской культуры / А. А. Казарницкий // Вестник археологии, антропологии и этнографии. 2010. - № 1 (12). - С. 132-140.

26. Казарницкий, А. А. Краниология населения майкопской культуры: «новые» старые материалы / А. А. Казарницкий // Археология, этнография и антропология Евразии. - 2010.- № 1 (41). - С. 148-155.

27. Казарницкий, А. А. Население Азово-Каспийских степей в эпоху бронзы (антропологический очерк) / А. А. Казарницкий. - СПб. : Наука, 2012. $-264 \mathrm{c}$.

28. Казарницкий, А. А. Краниология населения бабинской культуры / А. А. Казарницкий // Вестник археологии, антропологии и этнографии. 2013. - № 2 (21). - С. 70-78.

29. Казарницкий, А. А. Краниология носителей посткатакомбных культур / А. А. Казарницкий // Археологические источники и культурогенез. Проблемы периодизации и хронологии в археологии эпохи раннего металла Восточной Европы : материалы темат. науч. конф. - СПб. : Скифия принт, 2013. - C. 54-60.

30. Казарницкий, А. А. О краниологических особенностях носителей ямной археологической культуры Северо-Западного Прикаспия / А. А. Казарницкий // Археология, этнография и антропология Евразии. - 2014. - № 1 (57). - С. 142-150.

31. Китов, Е. П. Палеоантропология населения Южного Урала эпохи бронзы : автореф. дис. ... канд. ист. наук / Е. П. Китов. - М., 2011. - 26 с.

32. Кияшко, А. В. Динамика культурных изменений на территории восточноевропейских степей в эпоху бронзы / А. В. Кияшко // НАВ. - 2000. № 3. - С. 58-63.

33. Кияшко, А. В.Энеолит и культуры бронзового века Волго-Донских степей. По материалам археологических фондов Волгоградского областного краеведческого музея : каталог / А. В. Кияшко, Н. В. Хабарова ; под. науч. ред. А. С. Скрипкина, В. И. Мамонтова. - Волгоград : Панорама, 2007. - 118 с.

34. Кияшко, А. В. Эпохи энеолита, ранней и средней бронзы Волго-Донского региона / А. В. Кияшко // Археологическое наследие Волгоградской области. К 100-летию Волгоградского краеведческого музея / под ред. А. С. Скрипкина. - Волгоград : Издатель, 2013. - С. 45-63

35. Клейтман, А. Л. История Нижнего Поволжья в историографии петровского времени / А. Л. Клейтман // Genesis: исторические исследования. -2016. № 5. - C. 112-128.
36. Клейтман, А. Л. История Нижнего Поволжья в путевых заметках академика Н.Я. Озерецковского (1782-1783 гг.) / А. Л. Клейтман // Известия Волгоградского государственного педагогического университета. -2016. - № 8 (112). - С. 230-235.

37. Козловская, М.В. Экология древних племен лесной полосы Восточной Европы (антропологический очерк) / М. В. Козловская. - М. : Греко-Латин. каб., 1996. -243 с.

38. Круц, С. И. Палеоантропологические исследования Степного Поднепровья (эпоха бронзы) / С. И. Круц. - Киев : Наукова думка, 1984. $208 \mathrm{c}$.

39. Кузнецов, П. Ф. Особый тип металлических изделий ямной культуры (по результатам работ в Самарской долине) / П. Ф. Кузнецов, О. Д. Мочалов // Известия Самарского научного центра Российской академии наук. -2014. - Т. 16, № 3. - С. 291-297.

40. Курганы бронзового века в излучине Дона (опыт комплексных археологических и естественнонаучных исследований) / А. Н. Дьяченков, В. М. Клепиков, М. В. Кривошеев, М. А. Балабанова, Е. В. Перерва, Л. В. Яворская, А. В. Борисов, А. В. Демкин, Т. С. Демкина, С. Н. Удальцов, Т. Э. Хомутова. -Волгоград : Изд-во РАНХиГС, 2012. - 160 с.

41. Лапшин, А. С. Поздний бронзовый век / А. С. Лапшин // Археологическое наследие Волгоградской области. К 100-летию Волгоградского краеведческого музея / под ред. А. С. Скрипкина. - Волгоград : Издатель, 2013. - 288 с.

42. Медникова, М. Б. Древние скотоводы Южной Сибири: палеоэкологическая реконструкция по данным антропологии / М. Б. Медникова. - М. : ИА РАН, 1995. - $216 \mathrm{c}$.

43. Перерва, Е. В. Антропологические материалы из могильника Авиловский I и II / Е. В. Перерва // Материалы по археологии Волго-Донских степей: сб. ст. - Волгоград : Изд-во ВолГУ, 2004. - Вып. 2. C. $107-133$.

44. Перерва, Е. В. Предварительный палеопатологический анализ антропологических материалов, полученных в результате охранных археологических работ в зоне строительства магистрального газопровода Починки-Изобильное / Е. В. Перерва // Материалы по археологии Волго-Донских степей : сб. ст. - Волгоград : Изд-во ВолГУ, 2006. - Вып. 3. C. 293-336.

45. Перерва, Е. В. Палеопатологические особенности населения Нижнего Поволжья из подкурганных захоронений эпохи ранней бронзы / Е. В. Перерва // Известия Волгоградского государственного педагогического университета. - 2013. - № 8 (83). C. $47-53$.

46. Перерва, Е. В. Рентгенологическое исследование деформированных черепов эпохи средней бронзы с территории Нижнего Поволжья (палео- 
патологический аспект) / Е. В. Перерва // Вестник Волгоградского государственного университета. Серия 4, История. Регионоведение. Международные отношения. - 2013. - № 2 (24). - С. 7-19. DOI: http://doi.org/10.15688/jvolsu4.2013.2.1.

47. Перерва, Е. В. К вопросу о патологических особенностях неполовозрелого и подросткового населения эпохи бронзы из покурганных захоронений Нижнего Поволжья / Е. В. Перерва // Экология древних и традиционных обществ : материалы V Междунар. науч. конф. - Тюмень : Изд-во ТГУ, 2016. - C. 51-57.

48. Перерва, Е. В. Маркер стресса или миграций (к вопросу об интерпретации экзостоза слухового прохода на костных материалах населения эпохи средней бронзы из могильников Нижнего Поволжья) / Е. В. Перерва, А. Н. Дьяченко // Вестник археологии, антропологии и этнографии. - 2017. № 4 (39). - С. 61-78.

49. Перри, Дж. Состояние России при нынешнем царе / Дж. Перри. - М. : В Унив. тип., 1871. $193 \mathrm{c}$

50. Путешествие через Московию Корнилия де Бруина / пер. с фр. П. П. Барсова, пров. по гол. подлиннику О. М. Водянским. - М. : В Унив. тип., 1873. $328 \mathrm{c}$.

51. Рохлин, Д. Г.Болезни древних людей/ Д. Г. Рохлин. - М. ; Л. : Наука, 1965. - 304 с.

52. Рындина, Н. В. Энеолит и бронзовый век / Н. В. Рындина, А. Д. Дектярева. - М. : Изд-во МГУ, 2002. $-226 \mathrm{c}$.

53. Скрипкин, А. С. История Волгоградской земли от древнейших времен до современности / А. С. Скрипкин, А. В. Луночкин, А. В. Курилла. М. : Планета, 2013. - 224 с.

54. Хохлов, А. А. Краниологический тип человека, погребенного по традициям Майкопской культуры, эпохи ранней бронзы (Калмыкия, памятник Манджикины I, 14/13) / А. А. Хохлов // НАВ. -2002. № 5. - С. 174-179.

55. Хохлов, А. А. Палеоантропологический анализ погребений эпохи бронзы курганной группы Манджикины Республики Калмыкия / А. А. Хохлов, С. Б. Боруцкая // Экология и демография человека в прошлом и настоящем : тр. Третьих антропол. чтений к 75-летию со дня рождения акад. В.П. Алексеева. - М. : Энцикл. рос. деревень, 2004. -С. 218-219.

56. Хохлов, А. А. О краниологических особенностях населения ямной культуры Северо-Западного Прикаспия / А. А. Хохлов // Вестник археологии, антропологии и этнографии. - 2006. - № 14. С. 136-146.

57. Хохлов, А. А. К вопросу о монголоидных черепах эпохи бронзы Волго-Уралья / А. А. Хохлов // Magistra Vitae : электрон. журн. по ист. наукам и археологии. - 2009. - № 6 (144). - С. 8-11.
58. Хохлов, А. А. Палеоантропология ВолгоУралья эпох неолита - бронзы : автореф. дис. ... д-ра ист. наук / А. А. Хохлов. - М., 2013. - 34 с.

59. Хохлов, А. А. Краниологические материалы из древнейших подкурганных захоронений Бережновского типа / А. А. Хохлов // Известия Самарского научного центра Российской академии наук. 2013. - T. 15. - С. 196-199.

60. Краниологические данные к проблеме связи популяций ямной и афанасьевской культур Евразии начального этапа бронзового века / А. А. Хохлов [и др.] // Вестник археологии, антропологии и этнографии. -2016. - № 3 (34). - С. 86-106.

61. Хохлов, А. А. Морфогенетические процессы в Волго-Уралье в эпоху раннего голоцена (по краниологическим материалам мезолита - бронзового века) / А. А. Хохлов. - Самара : Изд-во СамГСПУ, 2017. $-368 \mathrm{c}$.

62. Хохлов, А. А. Теоретические и практические аспекты проблемы происхождения физического облика носителей культур синташтинского круга позднего этапа эпохи бронзы / А. А. Хохлов, Е. П. Китов // Поволжская археология. - 2019. № 1 (27). - С. 59-71.

63. Шевченко, А. В. Новые материалы по палеоантропологии Нижнего Поволжья (эпоха бронзы) / А. В. Шевченко // Проблемы этнической антропологии и морфологии человека. - Л. : Наука, 1974. - С. 123-135.

64. Шевченко, А. В. Антропология населения южнорусских степей в эпоху бронзы / А. В. Шевченко // Антропология древнего и современного населения европейской части СССР. - Л. : Наука, 1986. - С. 121-215.

65. Шевченко, А. В. Палеоантропология срубников Поволжья в сравнительно-антропологическом освещении / А. В. Шевченко // Археология России. Свод археологических источников. Т. 1. Памятники срубной культуры. Волго-Уральское междуречье. - Саратов : Изд-во Сарат. гос. ун-та, 1993. C. $101-105$.

66. Шишлина, Н. И. К вопросу о сезонной системе использования пастбищ носителями ямной культуры прикаспийских степей в III тыс. до н. э. / Н. И. Шишлина, В. Э. Булатов // ТГИМ. - 2000. Вып. 120. - С. 43-53.

67. Фирштейн, Б. В. Антропологическая характеристика населения Нижнего Поволжья в эпоху бронзы : (По материалам из раскопок в Волгоградской и Саратовской областях и в Калмыцкой АССР) / Б. В. Фирштейн // Памятники эпохи бронзы юга европейской части СССР. - Киев : Наукова думка, 1967. - С. 100-142.

68. Яблонский, Л. Т. Эпоха поздней бронзы раннего железа в Приаралье и проблема происхождения культур сакского типа / Л. Т. Яблонский 
// Степи Евразии в древности и Средневековье : материалы Междунар. науч. конф., посвященной 100летию со дня рождения М.П. Грязнова. - СПб. : Гос. Эрмитаж ; РАН ; Ин-т истории матер. культуры, 2003. - C. 201-203.

\section{REFERENCES}

1. Balabanova M.A. Katakombnaya kultura Volgo-Donskogo mezhdurechya po antropologicheskim dannym [Catacomb Culture of the Volga-Don Interfluve According to Anthropological Data]. Arkheologiya Nizhnego Povolzhya: problemy, poiski, otkrytiya: materialy III Mezhdunarodnoy Nizhnevolzhskoy arkheologicheskoy konferentsii (g. Astrakhan, 1821 oktyabrya 2010 g.) [Archaeology of the Lower Volga Region: Problems, Searches, Discoveries: Proceedings of the $3^{\text {rd }}$ International Lower Volga Archaeological Conference (Astrakhan, October 1821, 2010)]. Astrakhan, Izd-vo Astrakhanskogo universiteta, 2010, pp. 48-50.

2. Balabanova M.A. K antropologii naseleniya eneolita - ranney bronzy (po materialam mogilnikov Volgogradskoy oblasti) [On the Anthropology of the Population of the Eneolithic-Early Bronze (Based on the Burial Grounds of Volgograd Region)]. Nizhnevolzhskiy arkheologicheskiy vestnik [The Lower Volga Archaeological Bulletin], 2016, iss. 15, no. 1, pp. $72-94$.

3. Balabanova M.A. Detskie pogrebeniya srubnoy kulturno-istoricheskoy obshchnosti kak obekt mezhdistsiplinarnogo issledovaniya [Children's Burials of Srubna Cultural and Historical Community as an Object of Interdisciplinary Research]. Stratum plus: Archaeology and Cultural Anthropology, 2018. no. 2, pp. 245-258.

4. Balabanova M.A. Antropologicheskiy aspekt obychaya iskusstvennoy deformatsii cherepa $u$ naseleniya epokhi sredney bronzy Nizhnego Povolzhya i sopredelnykh territoriy [The Anthropological Aspect of the Skull Artificial Deformation Custom of the Population of the Middle Bronze Age of the Lower Volga Region and Adjacent Territories]. Samarskiy nauchnyy vestnik [Samara Journal of Science], 2018, vol. 7, no. 4(25), pp. 219-227. DOI: 10.24411/2309-43702018-14210.

5. Batieva E.F. Antropologiya srubnoabashevskikh pogrebeniy mezhdurechya Dona i Chira [Anthropology of Log-Abashev Burials Between the Don and Chir Rivers]. Vestnik antropologii [Herald of Anthropology], 1999, no. 6, pp. 130-139.

6. Batieva E.F. Novye materialy po antropologii Nizhnego Podonya [New Materials on the Anthropology of the Lower Don Region]. Vestnik Antropologii, Almanakh [Herald of Anthropology. Almanac], 2001, iss. 7, pp. 116-124.
7. Batieva E.F. Paleodemografiya Podonya i Priazovya (epokha bronzy) [The Paleodemography of the Don's and Azov's Region (in the Bronze Age)]. Vestnik antropologii [Herald of Anthropology], 2007, iss. 15, part 2, pp. 236-245.

8. Batieva E.F. K voprosu ob iskusstvennoy deformatsii cherepa na Nizhnem Donu v epokhu sredney bronzy [On the Issue of Artificial Deformation of the Skull on the Lower Don During the Middle Bronze Age]. Aktualnye napravleniya antropologii. Sbornik, posvyashchennyy yubileyu akademika RAN T.I. Alekseevoy [Current Trends in Anthropology. Collection Dedicated to the Anniversary of Academician of the Russian Academy of Sciences T. I. Alekseeva.]. Moscow, IA RAN, 2008, pp. 26-33.

9. Batieva E.F. Geografiya antropologicheskikh tipov drevnego naseleniya Nizhnego Podonya (Epokha bronzy - srednevekove) [Geography of Anthropological Types of the Ancient Population of the Lower Don (the Bronze Era - the Middle Ages)]. Arkheologicheskie zapiski. Sbornik nauchnykh statey [Archaeological Notes. Collection of Scientific Articles]. Rostov-on-Don, Donskoe arkheologicheskoe obshchestvo, 2013, iss. 8, pp. 236-245.

10. Belevy puteshestviya chrez Rossiyu v raznyya asiyatskiya zemli, a imenno: v Ispagan, v Pekin, v Derbent $i$ Konstantinopol [Belev's Travels Through Russia to Different Asiatic Lands, Namely: To Spasigan, to Beijing, to Derbent and Constantinople]. Saint Petersburg, Pri Imperatorskoy Akademii nauk, 1776 , part 3. $246 \mathrm{p}$.

11. Borutskaya S.B. Osobennosti fizicheskogo tipa naseleniya epokhi bronzy Severnogo Prikaspiya i Rostovskoy oblasti [Features of the Physical Type of the Population of the Bronze Age of the Northern Caspian and Rostov Region]. Pozdnekaynozoyskaya geologicheskaya istoriya severa aridnoy zony. Materialy mezhdunarodnogo simpoziuma [Late Cenozoic Geological History of the North of the Arid Zone. Proceedings of the International Symposium]. Rostov-on-Don, Izd-vo Rostovskogo gosudarstvennogo universiteta, 2006, pp.194-196.

12. Borutskaya S.B. Paleodemograficheskie, osteologicheskie i paleopatologicheskie aspekty issledovaniya populyatsii sredney bronzy Respubliki Kalmykiya [Paleodemographic, Osteological and Paleopathological Aspects of Studying Middle Bronze Populations of the Republic of Kalmykia]. Rol estestvennonauchnykh metodov $v$ arkheologicheskikh issledovaniyakh [The Role of Natural Science Methods in Archaeological Research]. Barnaul, Izd-vo Altayskogo gosudarstvennogo universiteta, 2009, pp. 289-293.

13. Bochkarev V.S. Kulturogenez i razvitie metalloproizvodstva $\mathrm{v}$ epokhu pozdney bronzy (po materialam yuzhnoy poloviny Vostochnoy Evropy) 
[Cultural Genesis and Metal Production Development in the Late Bronze Age (Based on Materials from the Southern Part of Eastern Europe)]. Drevnie indoiranskie kultury Volgo-Uralya (II tys. do n. e.) Mezhvuzovskiy sbornik nauchnykh trudov [Ancient Indo-Iranian Cultures of the Volga-Urals ( $2^{\text {nd }}$ Millennium BC). Interuniversity Collected Scientific Works]. Samara, Izd-vo SamGU, 1995, pp. 114-123.

14. Buzhilova A.P. Drevnee naselenie: (Paleopatologicheskie aspekty issledovaniya) [Ancient Population: (Paleopathological Aspects of Research)]. Moscow, IA RAN, 1995. 189 p.

15. Buzhilova A.P. Homo sapiens: Istoriya bolezni [Homo Sapiens: Medical History]. Moscow, Yazyki slavyanskikh kultur Publ, 2005. 320 p.

16. Vuich L.G. Cherepa iz kurganov epokhi bronzy i sarmatskogo vremeni na levom beregu Nizhnego Dona [Skulls from the Barrows of the Bronze and Sarmatian Epochs on the Left Bank of the Lower Don]. Materialy i issledovaniya po arkheologii SSSR, 1958, no. 62, pp. 418-425.

17. Gerasimova M.M. K voprosu o proiskhozhdenii yamnoy kultury [To the Issue of the Pit Grave Culture Origin]. Vestnik antropologii [Herald of Anthropology], 2011, no. 19, pp. 104-111.

18. Ginzburg V.V. Etnicheskie svyazi drevnego naseleniya [Ethnic Connections of the Ancient Population]. Materialy $i$ issledovoniya po archeologii SSSR, 1959, no. 60, pp. 324-594.

19. Maykova T. S., Preobrazhenskiy A.A., eds. Gistoriya Sveyskoy voyny (Podennaya zapiska Petra Velikogo) [The History of the Swedish War (Peter the Great's Day Note)]. Moscow, Krug Publ., 2004, iss. 1. $632 \mathrm{p}$.

20. Glazkova N.M., Chtetsov V.P. Paleoantropologicheskie materialy nizhnevolzhskogo otryada stalingradskoy ekspeditsii [Paleoanthropological Materials of the Lower Volga Detachment of the Stalingrad Expedition]. Materialy $i$ issledovonia po archeologii SSSR, 1960, no. 78, pp. 285-292.

21. Debets G.F. Materialy po paleoantropologii SSSR. Nizhnee Povolzhe [Materials on the Paleoanthropology of the USSR. Lower Volga]. Antropologicheskiy zhurnal, 1936, no. 1, pp. 65-80.

22. Debets G.F. Paleoantropologiya SSSR [Paleoanthropology of the USSR]. Moscow, Izd-vo akademii nauk SSSR, 1948. 389 p.

23. Derums V.Ya. Bolezni i vrachevanie v staroy Pribaltike [Diseases and Healing in the Old Baltics]. Riga, Zinatne Publ., 1970. 199 p.

24. Iroshnikov M.P., ed. Zapiski kapitana Filippa Ioganna Stralenberga ob istorii $i$ geografii Rossiyskoy imperii Petra Velikogo. Severnaya $i$ Vostochnaya chast Evropy [Captain Philip Johan Stralenberg's Notes on the History and Geography of the Russian Empire of Peter the Great. Northern and Eastern Europe]. Moscow, Leningrad, Institut istorii SSSR AN SSSR, 1985, vol. 1, 446 p.

25. Kazarnitskiy A.A. Kraniologiya naseleniya lolinskoy kultury [Craniology of the Population of Lolin Culture]. Vestnik arkheologii, antropologii $i$ etnografii [Vestnik Arheologii, Antropologii i Etnografii], 2010, no. 1 (12), pp. 132-140.

26. Kazarnitskiy A.A. Kraniologiya naseleniya maykopskoy kultury: "novye" starye materialy [Craniology of the Maikop Culture: "New" Old Materials]. Vestnik arkheologii, antropologii $i$ etnografii [Vestnik Arheologii, Antropologii i Etnografii], 2010, no. 1 (41), pp. 148-155.

27. Kazarnitskiy A.A. Naselenie AzovoKaspiyskikh stepey $v$ epokhu bronzy (antropologicheskiy ocherk). [Population of the Azov-Caspian Steppes in the Bronze Age (Anthropological Essay)]. Saint Peterburg, 2012.264 p.

28. Kazarnitskiy A.A. Kraniologiya naseleniya babinskoy kultury [Craniology of the Babin Culture]. Vestnik arkheologii, antropologii $i$ etnografii [Vestnik Arheologii, Antropologii i Etnografii], 2013, no. 2 (21), pp. 70-78.

29. Kazarnitskiy A.A. Kraniologiya nositeley postkatakombnykh kultur [Craniology of Postcatacomb Culture Representatives]. Arkheologicheskie istochniki i kulturogenez. Problemy periodizatsii i khronologii $v$ arkheologii epokhi rannego metalla Vostochnoy Evropy. Materialy tematicheskoy nauchnoy konferentsii [Archaeological Sources and Cultural Genesis. Problems of Periodization and Chronology in the Archaeology of the Early Metal Period of Eastern Europe. Proceedings of the Thematic Scientific Conference]. Saint Petersburg, Scythia Print., 2013, pp. 54-60.

30. Kazarnitskiy A.A. O Kraniologicheskikh osobennostyakh nositeley yamnoy arkheologicheskoy kultury Severo-Zapadnogo Prikaspiya [About Craniological Features of the Pit Archaeological Culture Representatives of North-Western Pre-Caspian]. Arkheologiya, etnografiya $i$ antropologiya Evrazii [Archeology, Ethnography and Anthropology of Eurasia], 2014, no. 1(57), pp. 142-150.

31. Kitov E.P. Paleoantropologiya naseleniya Yuzhnogo Urala epokhi bronzy: avtoref. dis. ... kand. ist. nauk. [Paleoanthropology of the Population of the Southern Urals of the Bronze Age. Cand. hist. sci. diss.]. Moscow, 2011. 26 p.

32. Kiyashko A.V. Dinamika kulturnykh izmeneniy na territorii vostochnoevropeyskikh stepey v epokhu bronzy [The Dynamics of Cultural Changes on the Territory of the Eastern European Steppes in the Bronze Age]. Nizhnevolzhskiy arkheologicheskiy vestnik [The Lower Volga Archaeological Bulletin], 2000, no. 3, pp. 58-63. 
33. KiyashkoA.V., Khabarova N.V. Eneolit i kultury bronzovogo veka Volgo-Donskikh stepey. Po materialam arkheologicheskikh fondov Volgogradskogo oblastnogo kraevedcheskogo muzeya: katolog [Eneolithic and Bronze Age Cultures of the Volga-Don Steppes. According to the Materials of Archaeological Funds of the Volgograd Regional Museum of Local Lore. Catalogue]. Volgograd, Panorama Publ., 2007. 118 p.

34. Kiyashko A.V. Epokhi eneolita, ranney i sredney bronzy Volgo-Donskogo regiona [Eneolithic, Early and Middle Bronze Eras of the Volga-Don Region]. Skripkin A.S., ed. Arkheologicheskoe nasledie Volgogradskoy oblasti. K 100-letiyu Volgogradskogo kraevedcheskogo muzeya [Archaeological Heritage of Volgograd Region. To the $100^{\text {th }}$ Anniversary of the Volgograd Regional Museum of Local Lore]. Volgograd, Izdatel Publ., 2013, pp. 45-63.

35. Kleytman A.L. Istoriya Nizhnego Povolzhya v istoriografii petrovskogo vremeni [The history of the Lower Volga Region in the Historiography of Peter the Great's Time]. Genesis: istoricheskie issledovaniya [Genesis: Historical Research], 2016, no. 5, pp. 112-128.

36. Kleytman A.L. Istoriya Nizhnego Povolzhya v putevykh zametkakh akademika N.Ya. Ozeretskovskogo (1782-1783 gg.) [The History of the Lower Volga Region in Travel Notes of Academician N.Ya. Ozeretskovsky (17821783). Izvestiya Volgogradskogo gosudarstvennogo pedagogicheskogo universiteta [Ivzestia of the Volgograd StatePedagogicalUniversity], 2016, no. 8(112), pp. 230-235.

37. Kozlovskaya M.V. Ekologiya drevnikh plemen lesnoy polosy Vostochnoy Evropy (antropologicheskiy ocherk) [Ecology of the Ancient Tribes of the Forest Belt of Eastern Europe (Anthropological Essay)]. Moscow, Greko-latinskiy cabinet, 1996. $243 \mathrm{p}$.

38. Kruts S.I. Paleoantropologicheskie issledovaniya Stepnogo Podneprovya (epokha bronzy) [Paleoanthropological Studies of the Steppe Dnieper Region (Bronze Age)]. Kiev, Naukova dumka Publ., 1984. 208 p.

39. Kuznetsov P.F., Mochalov O.D. Osobyy tip metallicheskikh izdeliy yamnoy kultury (po rezultatam rabot v Samarskoy doline) [Special Type of Metal Items of the Pit Grave Culture (Based on the Results of Works in Samara Valley)]. Izvestiya Samarskogo nauchnogo tsentra Rossiyskoy akademii nauk [Izvestia of Samara Scientific Center of the Russian Academy of Sciences], 2014, vol. 16, no. 3, pp. 291-297.

40. DyachenkoA.N., Klepikov V.M., Krivosheev M.V., Balabanova M.A., Pererva E.V., Yavorskaya L.V., Borisov A.V., Demkin A.V., Demkina T.S., Udaltsov S.N., Khomutova T.E. Kurgany bronzovogo veka v izluchine Dona (opyt kompleksnykh arkheologicheskikh $i$ estestvennonauchnykh issledovaniy) [Bronze Age
Mounds in the Bend of the Don (Experience of Complex Archaeological and Natural Science Research)]. Volgograd, 2012. $160 \mathrm{p}$.

41. Lapshin A.S. Pozdniy bronzovyy vek [Late Bronze Age]. Skripkin A.S., ed. Arkheologicheskoe nasledie Volgogradskoy oblasti. K 100-letiyu Volgogradskogo kraevedcheskogo muzeya. [Archaeological Heritage of Volgograd Region. To the $100^{\text {th }}$ Anniversary of the Volgograd Regional Museum of Local Lore]. Volgograd, Izdatel Publ., 2013. 288 p.

42. Mednikova M.B. Drevnie skotovody Yuzhnoy Sibiri: paleoekologicheskaya rekonstruktsiya po dannym antropologii [Ancient Pastoralists of Southern Siberia: Paleoecological Reconstruction According to Anthropology Data]. Moscow, IA RAN, 1995.216 p.

43. Pererva E.V. Antropologicheskie materialy iz mogilnika Avilovskiy I i II [Anthropological Materials from Avilovsky Burial Mound I and II]. Materialy po arkheologii Volgo-Donskikh stepey: sbornik statey [Materials on the Archaeology of the Volga-Don Steppes: Collected Articles]. Volgograd, Izd-vo VolGU, 2004, iss. 2, pp. 107-133.

44. Pererva E.V. Predvaritelnyy paleopatologicheskiy analiz antropologicheskikh materialov, poluchennykh $\mathrm{v}$ rezultate okhrannykh arkheologicheskikh rabot $\mathrm{V}$ zone stroitelstva magistralnogo gazoprovoda PochinkiIzobilnoe [Preliminary Paleopathological Analysis of Anthropological Materials Obtained as a Result of Protective Archaeological Works in the Construction Area of the Pochinki-Izobilnoe Gas Pipeline]. Materialy po arkheologii Volgo-Donskikh stepey: Sbornik statey [Materials on the Archaeology of the VolgaDon Steppes: Collected Articles]. Volgograd, Izd-vo VolGU, 2006, iss. 3, pp. 293-336.

45. Pererva E.V. Paleopatologicheskie osobennosti naseleniya Nizhnego Povolzhya iz podkurgannykh zakhoroneniy epokhi ranney bronzy [Paleopathological Features of the Population of the Lower Volga Region from the Burial Grounds of the Early Bronze Age]. Izvestiya Volgogradskogo gosudarstvennogo pedagogicheskogo universiteta [Ivzestia of the Volgograd State Pedagogical University], 2013, no. 8 (83), pp. 47-53.

46. Pererva E.V. Rentgenologicheskoe issledovanie deformirovannykh cherepov epokhi Sredney Bronzy s territorii Nizhnego Povolzhya (paleopatologicheskiy aspekt) [X-ray Study of Deformed Skulls of the Middle Bronze Age from the Lower Volga Region (Paleopathological Aspect)]. Vestnik Volgogradskogo gosudarstvennogo universiteta. Seriya 4. Istoriya. Regionovedenie. Mezhdunarodnye otnosheniya [Science Journal of Volgograd State University. History. Area Studies. International Relations], 2013, no. 2(24), pp. 7-19. DOI: http://doi.org/10.15688/jvolsu4.2013.2.1. 
47. Pererva E.V. K voprosu o patologicheskikh osobennostyakh nepolovozrelogo i podrostkovogo naseleniya epokhi bronzy iz pokurgannykh zakhoroneniy Nizhnego Povolzhiya [On the Issue of the Pathological Features of the Immature and Adolescent Population of the Bronze Age from the Burial Grounds of the Lower Volga Region]. Ekologiya drevnikh i traditsionnykh obshchestv: materialy $V$ Mezhdunarodnoy nauchnoy konferentsii [Ecology of Ancient and Traditional Societies. Materials of the $5^{\text {th }}$ International Scientific Conference]. Tyumen, Izd-vo TGU, 2016, pp. 51-57.

48. Pererva E.V., Dyachenko A.N. Marker stressa ili migratsiy ( $\mathrm{k}$ voprosu ob interpretatsii ekzostoza slukhovogo prokhoda na kostnykh materialakh naseleniya epokhi sredney bronzy iz mogilnikov Nizhnego Povolzhya) [Marker of Stress or Migration (To the Issue of the Interpretation of the Auditory Canal Exostosis on Bone Materials of the Middle Bronze Age Population from the Burial Grounds of the Lower Volga Region)]. Vestnik arkheologii, antropologii i etnografii [Vestnik Arheologii, Antropologii i Etnografii], 2017, no. 4 (39), pp. 61-78.

49. Perri, Dzh. Sostoyanie Rossii pri nyneshnem tsare [The State of Russia Under the Present Tsar]. Moscow, Universitetskaya tipografiya, 1871. 193 p.

50. Puteshestvie cherez Moskoviyu Korniliya de Bruina [Journey through Muscovy of Cornelius de Bruin]. Moscow, Universitetskaya tipografiya, 1873.328 p.

51. Rokhlin D.G. Bolezni drevnikh lyudey [Diseases of Ancient People]. Moscow, Leningrad, Nauka Publ., 1965. 304 p.

52. Ryndina N.V., Dektyareva A.D. Eneolit $i$ bronzovyy vek [Aeneolithic and Bronze Age]. Moscow, Izd-vo MGU, 2002. 226 p.

53. Skripkin A.S., Lunochkin A.V., Kurilla A.V. Istoriya Volgogradskoy zemli ot drevneyshikh vremen do sovremennosti [The History of the Volgograd Land from Ancient Times to Modernity]. Moscow, Planeta Publ., 2013. 224 p.

54. Khokhlov A.A. Kraniologicheskiy tip cheloveka, pogrebennogo po traditsiyam Maykopskoy kultury, epokhi ranney bronzy (Kalmykiya, pamyatnik Mandzhikiny I, 14/13) [Craniological Type of a Person Buried According to the Traditions of the Maikop Culture, the Early Bronze Age (Kalmykia, Monument to Mandzhikin I, 14/13)]. Nizhnevolzhskiy arkheologicheskiy vestnik [The Lower Volga Archaeological Bulletin], 2002, no. 5, pp. 174-179.

55. Khokhlov A.A., Borutskaya S.B. Paleoantropologicheskiy analiz pogrebeniy epokhi bronzy kurgannoy gruppy Mandzhikiny respubliki Kalmykiya [The Paleoanthropological Analysis of the Burials of the Bronze Age Barrow Group Manjikani of the Republic of Kalmykia]. Ekologiya i demografiya cheloveka v proshlom i nastoyashchem: tr. Tretikh antropol. Chteniy $k$ 75-letiyu so dnya rozhdeniya akad. V.P. Alekseeva [Ecology and Demography of a Person in the Past and the Present: Proceedings of the Third Anthropological Readings on the $75^{\text {th }}$ Anniversary of Academician V.P. Alekseev]. Moscow, Entsiklopediya rossiyskikh dereven, 2004, pp. 218-219.

56. Khokhlov A.A. O kraniologicheskikh osobennostyakh naseleniya yamnoy kultury SeveroZapadnogo Prikaspiya [On the Cranial Features of the North-West Caspian Yamnaya (Pit-Grave) Culture Population]. Vestnik arkheologii, antropologii $i$ etnografii [Vestnik Arheologii, Antropologii i Etnografii], 2006, no. 14, pp. 136-146.

57. Khokhlov A.A. K voprosu o mongoloidnykh cherepakh epokhi bronzy Volgo-Uralya [To the Issue of Mongoloid Skulls of the Bronze Age of the VolgaUral]. Magistra Vitae: elektronnyy zhurnal po istoricheskim naukam i arkheologii [Magistra Vitae], 2009, no. 6(144), pp. 8-11.

58. Khokhlov A.A. Paleoantropologiya VolgoUralya epokh neolita-bronzy: avtoref. dis. ... d-ra ist. nauk. [Paleoanthropology of the Volga-Urals of the Neolithic-Bronze Epochs. Dr. hist. sci.. diss.]. Moscow, 2013.34 p.

59. Khokhlov A.A. Kraniologicheskie materialy iz drevneyshikh podkurgannykh zakhoroneniy Berezhnovskogo tipa [Craniological Materials from the Most Ancient Burial Grounds of Berezhnovsky Type]. Izvestiya Samarskogo nauchnogo tsentra Rossiyskoy akademii nauk [Izvestia of Samara Scientific Center of the Russian Academy of Sciences], 2013, vol. 15, pp. 196-199.

60. Khokhlov A.A., Solodovnikov K.N., Rykun M.P., Kravchenko G.G., Kitov E.P. Kraniologicheskie dannye k probleme svyazi populyatsiy yamnoy $\mathrm{i}$ afanasevskoy kultur Evrazii nachalnogo etapa bronzovogo veka [Craniological Data on the Problem of the Connection of Populations of the Pit Grave and Afanasyev Cultures of Eurasia at the Initial Stage of the Bronze Age]. Vestnik arkheologii, antropologii $i$ etnografii [Vestnik Arheologii, Antropologii i Etnografii], 2016, no. 3 (34), pp. 86-106.

61. Khokhlov A.A. Morfogeneticheskie protsessy $v$ Volgo-Urale $v$ epokhu rannego golotsena (po kraniologicheskim materialam Mezolita-Bronzovogo veka) [Morphogenetic Processes in the Volga-Urals in the Era of the Early Holocene (According to the Craniological Materials of the Mesolithic-Bronze Age)]. Samara, Izd-vo SamGSPU, 2017.368 p.

62. Khokhlov A.A., Kitov E.P. Teoreticheskie i prakticheskie aspekty problemy proiskhozhdeniya fizicheskogo oblika nositeley kultur sintashtinskogo kruga pozdnego etapa epokhi bronzy [Theoretical and Practical Aspects of the Origin of the Physical Appearance of Sintashta Circle Culture Representatives of the Bronze Age Late Stage]. 
Povolzhskaya Arkheologiya [The Volga River Region Archaeology], 2019, no. 1 (27), pp. 59-71.

63. Shevchenko A.V. Novye materialy po paleoantropologii Nizhnego Povolzhya (epokha bronzy) [New Materials on the Paleoanthropology of the Lower Volga Region (Bronze Age)]. Problemy etnicheskoy antropologii i morfologii cheloveka [Problems of Ethnic Anthropology and Human Morphology]. Leningrad, Nauka Publ., 1974, pp. 123-135.

64. Shevchenko A.V. Antropologiya naseleniya yuzhnorusskikh stepey v epokhu bronzy [Anthropology of the Southern Russian Steppe Population in the Bronze Age]. Antropologiya drevnego i sovremennogo naseleniya Evropeyskoy chasti SSSR [Anthropology of the Ancient and Modern Population of the European Part of the USSR]. Leningrad, Nauka Publ., 1986, pp. 121-215.

65. Shevchenko A.V. Paleoantropologiya srubnikov Povolzhya V sravnitelno-antropologicheskom osveshchenii [Paleoanthropology of the Volga Region from the Comparative Anthropological Perspective]. Arkheologiya Rossii. Svod arkheologicheskikh istochnikov. Tom 1. Pamyatniki srubnoy kultury. VolgoUralskoe mezhdureche [Archaeology of Russia. Corpus of Archaeological Sources. Vol. 1. Monuments of the Timber-Grave Culture. The Volga-Ural Interfluve]. Saratov, Izd-vo Saratovskogo gosudarstvennogo universiteta, 1993,pp. 101-105.

66. Shishlina N.I., Bulatov V.E. K voprosu o sezonnoy sisteme ispolzovaniya pastbishch nositelyami yamnoy kultury prikaspiyskikh stepey $\mathrm{v}$ III tys. do n. e. [On the Issue of the Seasonal System of Pasture Use by the Representatives of the Pit Grave Culture of the Caspian Steppes in the $3^{\text {rd }}$ Millennium $\mathrm{BC}$ ]. Trudy Gosudarstvennogo istoricheskogo muzeya [Proceedings of the State Historical Museum], 2000, iss. 120 , pp. 43-53.

67. Firshtein B.V. Antropologicheskaya kharakteristika naseleniya Nizhnego Povolzhya v epokhu bronzy (Po materialam iz raskopok $\mathrm{v}$ Volgogradskoy i Saratovskoy oblastyakh i v Kalmytskoy ASSR) [Anthropological Characteristics of the Population of the Lower Volga Region in the Bronze Age (According to Materials from the Excavations in Volgograd and Saratov Regions and in the Kalmyk ASSR)]. Pamyatniki epokhi bronzy yuga evropeyskoy chasti SSSR [Monuments of the Bronze Age of the South of the European Part of the USSR]. Kiev, Naukova Dumka Publ., 1967, pp. 100-142.

68. Yablonskiy L.T. Epokha pozdney bronzy rannego zheleza v Priarale i problema proiskhozhdeniya kultur sakskogo tipa [The Late Bronze - Early Iron Epoch in the Aral Sea and the Problem of the Origin of Saka-Type Cultures]. Stepi Evrazii v drevnosti $i$ Srednevekove: materialy Mezhdunarod. nauch. konf., posvyashchennoy 100-letiyu so dnya rozhdeniya M.P. Gryaznova. [The Steppes of Eurasia in Antiquity and the Middle Ages. Proceedings of the International Scientific Conference Dedicated to the $100^{\text {th }}$ Anniversary of the Birth of Mikhail Petrovich Gryaznov]. Saint Petersburg, Gosudarstvennyy Ermitazh, RAN, Institut istorii materialnoy kultury, 2003, pp. 201-203.

\section{Information about the Authors}

Evgeny V. Pererva, Candidate of Sciences (History), Head of Science Department, Volgograd Institute of Management, Branch of the Russian Presidential Academy of National Economy and Public Administration, Gagarina St., 8, 400015 Volgograd, Russian Federation, perervafox@mail.ru, https://orcid.org/0000-0001-8285-4461

Alexandr N. Djachenko, Researcher, Laboratory of Archaeological Research, Volgograd State University, Prosp. Universitetsky, 100, 400062 Volgograd, Russian Federation, djachenko_an@mail.ru, https://orcid.org/0000-0002-4802-1922

\section{Информация об авторах}

Евгений Владимирович Перерва, кандидат исторических наук, начальник отдела науки, Волгоградский институт управления - филиал Российской академии народного хозяйства и государственной службы при Президенте РФ, ул. Гагарина 8, 400015 г. Волгоград, Российская Федерация, perervafox@mail.ru, https://orcid.org/0000-0001-8285-4461

Александр Николаевич Дьяченко, научный сотрудник лаборатории археологических исследований, Волгоградский государственный университет, просп. Университетский, 100, 400062 г. Волгоград, Российская Федерация, djachenko_an@mail.ru, https://orcid.org/0000-0002-4802-1922 